\title{
A Survey for Strains of Xylella fastidiosa in Citrus Affected by Citrus Variegated Chlorosis and Citrus Blight in Brazil
}

\author{
M. J. G. Beretta, Instituto Biologico, Sao Paulo, Brazil, CP07119,01064-970; and G. A. Barthe, T. L. Ceccardi, \\ R. F. Lee, and K. S. Derrick, Citrus Research and Education Center, IFAS, University of Florida, Lake Alfred 33850
}

\begin{abstract}
Beretta, M. J. G., Barthe, G. A., Ceccardi, T. L., Lee, R. F., and Derrick, K. S. 1997. A survey for strains of Xylella fastidiosa in citrus affected by citrus variegated chlorosis and citrus blight in Brazil. Plant Dis. 81:1196-1198.

Polymerase chain reaction amplification of DNA from various strains of Xylella fastidiosa with tRNA consensus primers produced three different fingerprint groups. The citrus variegated chlorosis (CVC) and mulberry leaf scorch strains were unique and readily separated from each other and all other strains tested. Internal primers were designed based on the sequence of a DNA fragment unique to the CVC strain. An assay was developed with a mixture of these primers and those reported to detect 18 strains of $X$. fastidiosa. The assay was used to survey citrus in Brazil. The strain identified to be the cause of CVC was found in constant association with trees with CVC symptoms. On occasion, trees with no symptoms were found to have the CVC strain; this was presumably due to presymptomatic infections. No other strains were found in this survey, and $X$. fastidiosa was not associated with citrus blight.
\end{abstract}

Citrus variegated chlorosis (CVC) was first observed in Brazil in 1987 (14). Since the initial observations, the disease has spread rapidly by graft propagation with infected budwood and by sharpshooter vectors and has become widely distributed in the citrus-growing regions of Brazil. CVC is now a major concern of the Brazilian citrus industry and is considered to be potentially more devastating than citrus blight (CB). $\mathrm{CB}$ is known as declinio in Brazil, where it affects an estimated 10 million trees a year (A. A. Amaro, personal communication). CVC has not been found in Florida, but approximately 1 million producing trees are lost to $\mathrm{CB}$ in the state each year (R. P. Muraro, personal communication). There are some similarities between CVC and CB: both diseases cause wilt symptoms due to xylem dysfunction and show zinc deficiency symptoms in leaves. CVC is caused by a strain of Xylella fastidiosa $(4,7,21)$, and there have been controversial reports associating the Pierce's disease (PD) strain of $X$. fastidiosa with CB in Florida $(9-11,18)$. We consider the cause of $\mathrm{CB}$ to be unknown, but it does appear to be infectious, because it is readily transmitted by rootgraft inoculations $(19,20)$. CB causes a nondescript decline that is difficult to diagnose

Corresponding author: K. S. Derrick

E-mail: ksd@icon.lal.ufl.edu

Florida Agricultural Experiment Station Journal Series R-05644.

Accepted for publication 9 July 1997.

Publication no. D-1997-0804-01R

(C) 1997 The American Phytopathological Society by symptoms alone. Trees with blight are identified by a water uptake test (15), elevated zinc in the wood (23), and, more recently, a serological test for a protein that accumulates in leaves of affected trees (5). All the diagnostic tests for $\mathrm{CB}$, including root-graft transmission, have been used to establish that blight in Florida and declinio in Brazil are indistinguishable (3). Prior to the discovery of CVC, the only disease caused by $X$. fastidiosa reported in Brazil was plum leaf scald. This disease was first reported in the delta of the Parana River in Argentina in 1935; in 1975 it was reported to have spread into southern Brazil (12).

In addition to more classical procedures based on culture, serology, and microscopy, a number of studies using molecular techniques for detection and strain characterization of $X$. fastidiosa have been reported (18). Recently, a variety of procedures for detection of $X$. fastidiosa by polymerase chain reaction (PCR) have been described $(6,16,17)$. A procedure was developed that detects most, if not all, strains with primers from a region of genomic DNA that is conserved in 18 strains (16). By screening with random amplified polymorphic DNA markers, gene fragments with sequences unique to the strain causing CVC were identified, and primers were designed that appear to be specific to that strain (17).

Welsh and McClelland (22) designed consensus tRNA primers for PCR that amplify DNA fragments from bacterial, plant, and animal genomic DNA. These primers generate genomic fingerprints that are largely conserved within a species. Applications of diagnostic tests based on tRNA primers and strategies used to develop such tests were reviewed recently (8).
We have developed a PCR procedure based on nested sequences derived from consensus tRNA primers that appears to be specific for the $X$. fastidiosa strain causing CVC. This procedure was used to show that a disease of coffee in Brazil appears to be caused by a strain of $X$. fastidiosa similar to the one causing CVC (2). We report here the use of PCR to survey for strains of $X$. fastidiosa in citrus in Brazil.

\section{MATERIALS AND METHODS}

Bacterial strains and plant material. Strains of $X$. fastidiosa were obtained from the American Type Culture Collection, Rockville, MD. Isolates of the CVC strain were cultured from midribs and petioles of leaves of infected citrus trees as previously described (7). CVC-affected trees were selected based on symptoms, which are usually diagnostic for the disease. CB-affected trees were selected initially based on general tree decline and wilt. Selected trees were confirmed to be affected by CB by a serological test for a blight-specific protein (5).

DNA isolations and PCR. DNA was isolated from cultures and midribs of leaves and petioles by a cetyltrimethylammoniumbromide procedure (1). DNA from approximately $100 \mathrm{mg}$ of tissue was suspended in a final volume of $50 \mathrm{ml}$ of water. PCR was conducted in 25-ml reactions with PCR buffer (Idaho Technology Inc., Idaho Falls, ID) with $2 \mathrm{mM} \mathrm{MgCl}$, $100 \mathrm{mM}$ each dNTP, 0.5 units of Taq DNA polymerase, $0.5 \mathrm{mM}$ each primer, and either $1 \mathrm{ml}$ of DNA from tissue or $50 \mathrm{ng}$ of DNA from cultured bacteria. The DNA was amplified at $95^{\circ} \mathrm{C}$ for $3 \mathrm{~min}$, followed by 35 cycles of $94^{\circ} \mathrm{C}$ for $30 \mathrm{~s}, 50^{\circ} \mathrm{C}$ for consensus primers for $30 \mathrm{~s}$, or $58^{\circ} \mathrm{C}$ for homologous primers for $30 \mathrm{~s}, 72^{\circ} \mathrm{C}$ for $90 \mathrm{~s}$, and a final extension of $7 \mathrm{~min}$ at $72^{\circ} \mathrm{C}$. Five milliliters of each reaction was analyzed on $10 \%$ polyacrylamide gels and stained with ethidium bromide. The consensus tRNA primers (22) used were T5B and T3A (Fig. 1A). Primers RST31 (5'GCGTTAATTTTCGAAGTGATTCGATTGC-3') and RST33 (5'-CACCATTCGTATCCCGGTG-3') detected 18 strains of $X$. fastidiosa (16) used in the mixed primer assay. Nested primers designed for specific detection of the CVC strain were designated CVC1 and CVC2 (Fig. 1A).

DNA cloning and sequencing. Selected PCR products were cloned with a TA cloning vector (Promega, Madison, WI). Clones were identified by PCR, and plasmid DNA was isolated for sequencing. DNA sequenc- 
ing was conducted in the Interdisciplinary Center for Biotechnology Research core facility at the University of Florida, Lake Alfred.

\section{RESULTS AND DISCUSSION}

PCR with the tRNA consensus primers T5B and T3A identified three fingerprint groups of $X$. fastidiosa (Fig. 2). The CVC and mulberry leaf scorch (MLS) strains were distinct and readily distinguished from each other and other strains. CVC DNA from cultures and infected plant tissue consistently produced a 164-bp fragment that migrated slightly faster than a 164-bp fragment from other strains of $X$. fastidiosa when analyzed on $10 \%$ polyacrylamide gels. There was considerable variation in the sequence of the 164-bp fragment from a CVC strain compared to that from a PD strain (Fig. 1B). The 164-bp fragment of all strains of $X$. fastidiosa, other than CVC, appear to have identical migration rates, suggesting minimal variations in sequence, but additional comparisons by sequencing these 164-bp fragments from strains of $X$. fastidiosa would be of interest.

A 391-bp fragment was produced with DNA from both CVC cultures and infected tissue extracts; this fragment was not observed with DNA from the other strains of $X$. fastidiosa (Fig. 2.). A fragment of about $330 \mathrm{bp}$ was observed from two strains of MLS that appears to distinguish MLS from the other $X$. fastidiosa diseases (Fig. 2); this was not investigated further in this study.

The sequence of the 391-bp fragment from CVC was used to design internal homologous primers for production of a predicted 270-bp fragment from the CVC strain (Fig. 1A). These primers were used in a mixed primer assay with the primers reported to produce a 733-bp fragment from 18 strains of $X$. fastidiosa (Fig. 3). PCR assays with mixtures of these two primer sets produced a 733-bp fragment from all strains of $X$. fastidiosa and an additional fragment of 270 bp from the CVC strain (Fig. 3). In some cases, faint 270-bp bands were seen with template DNA from cultures of strains other than CVC. This probably was due to the extreme sensitivity of PCR in detecting minute cross-contamination of samples.

Using the mixed primer assay, we surveyed citrus in Brazil that is affected by $\mathrm{CVC}$ and $\mathrm{CB}$. As expected, the CVC strain was found in constant association with symptoms of CVC (Fig. 3). On occasion, the CVC strain also was found in trees with no symptoms. In assays of more than 100 individual trees, no strains other than CVC were detected. Moreover, in a report on the presence of $X$. fastidiosa in coffee, as determined by PCR (2), a strain similar to the one causing CVC was detected.

Over the years there have been reports of the presence of $X$. fastidiosa in both healthy trees and trees with $\mathrm{CB}$ in Florida, and the PD strain of $X$. fastidiosa has been suggested as the cause of CB $(9-11,18)$. To our knowledge, PD has not been reported in Brazil, and the general consensus among Brazilian plant pathologists is that it is not present in that country. Thus, reports from Florida suggesting that $\mathrm{CB}$ is caused by $X$. fastidiosa are questionable.

Following the discovery of CVC in Brazil, numerous surveys were made in citrus groves for the presence of $X$. fasti$\operatorname{dios} a$, using serological techniques (13). In these surveys, $X$. fastidiosa was not associated with CB (M. J. G. Beretta, unpublished data). Using the mixed primer assay, we again failed to associate $X$. fastidiosa with $C B$ in Brazil. In a survey of healthy and blighted trees, only one positive reac-
AATGCTCTACCAACTGAACTACACCGGCAAAAACGAGAATGTCGCTACATCATGGCTGTACTGGGTCGCCTTGACAGGGC 80

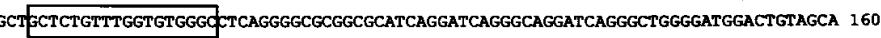

A

TATGTAGCCGTTGCAGGTGCGGTGTGGAGAGGGGAAGGCGCAGTGGTGCTGCTGTGGGTCTGGATGCGGCGACGGGGGTA 320 GCGCTCAGCA GCATAGAATTGCTCATACACCEPCACTCCATCGCTGGGGCCGGCGGGAATTCGAACCCCC

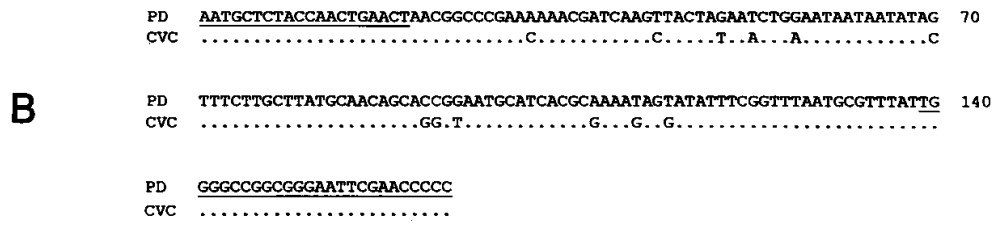

Fig. 1. (A) Sequence of a 391-bp fragment from citrus variegated chlorosis (CVC) DNA, obtained with $\mathrm{T} 5 \mathrm{~B}$ and $\mathrm{T} 3 \mathrm{~A}$ primers (underlined), that shows the position of internal primers $\mathrm{CVCl}$ and $\mathrm{CVC} 2$ (boxed). (B) Alignment of 164-bp fragments from polymerase chain reaction amplification of DNA from Pierce's disease and CVC with tRNA consensus primers T5B and T3A.

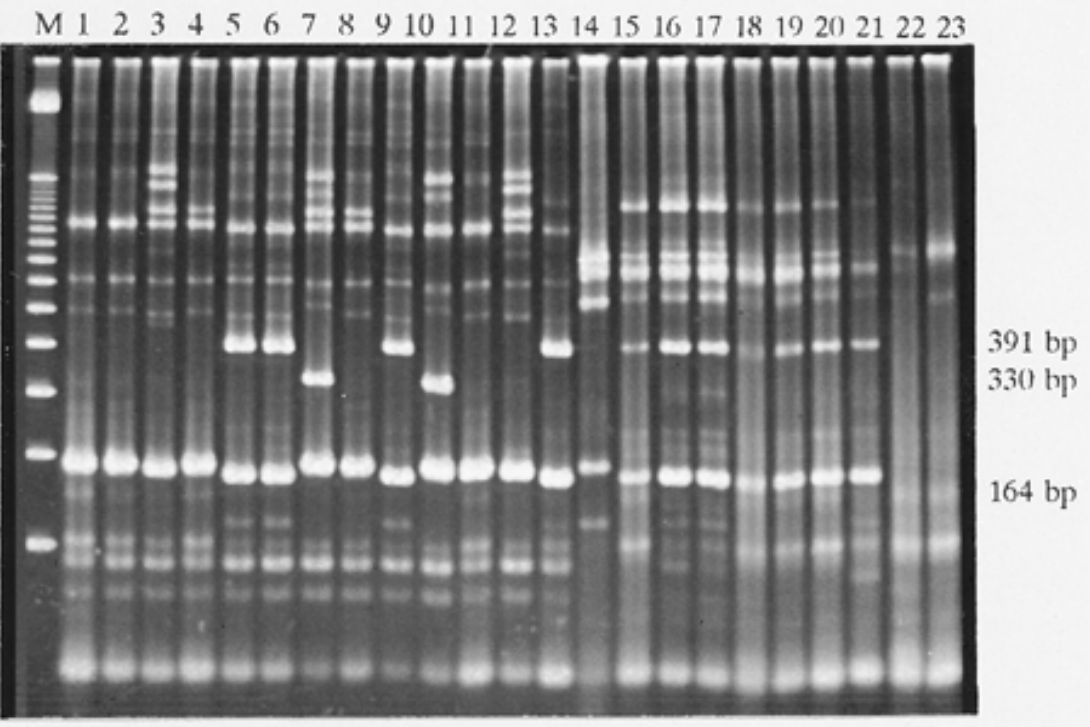

Fig. 2. Polyacrylamide gel electrophoresis of polymerase chain reaction-amplified gene fragments from Xylella fastidiosa strains with the tRNA consensus primers T5B and T3A. Lanes 1 through 13, cultures. Lane 1, Pierce's disease, Florida (ATCC 35881); lane 2, Pierce's disease, Florida (ATCC 35879); lane 3, elm leaf scorch, Washington (ATCC 35873); lane 4, ragweed, Florida (ATCC 358765); lane 5, citrus variegated chlorosis (CVC), Colina, Brazil; lane 6, CVC, Macaubal, Brazil; lane 7, mulberry leaf scorch, Massachusetts (ATCC 35869); lane 8, almond leaf scorch, California (ATCC 358709); lane 9, CVC, Catigua, Brazil; lane 10, mulberry leaf scorch, Massachusetts (ATCC 35868); lane 11, Pierce's disease, California (ATCC 35877); lane 12, oak leaf scorch, Washington (ATCC 35874); and lane 13, Vinca rosea inoculated with CVC culture, Sao Paulo, Brazil. Lanes 14 through 23, extracts of citrus: lanes 14, 22, and 23, from symptomless trees; and lanes 15 through 21 , from trees with CVC symptoms. Lane 14, Florida; lane 15, Bebedouro, Brazil; lanes 16 and 17, Macaubal, Brazil; lane 18, Colina, Brazil; lanes 19 and 20, Catigua, Brazil; lane 21, Monte Aprazivel, Brazil; and lanes 22 and 23, Sao Paulo, Brazil. Lane M, 100-bp DNA ladder. 

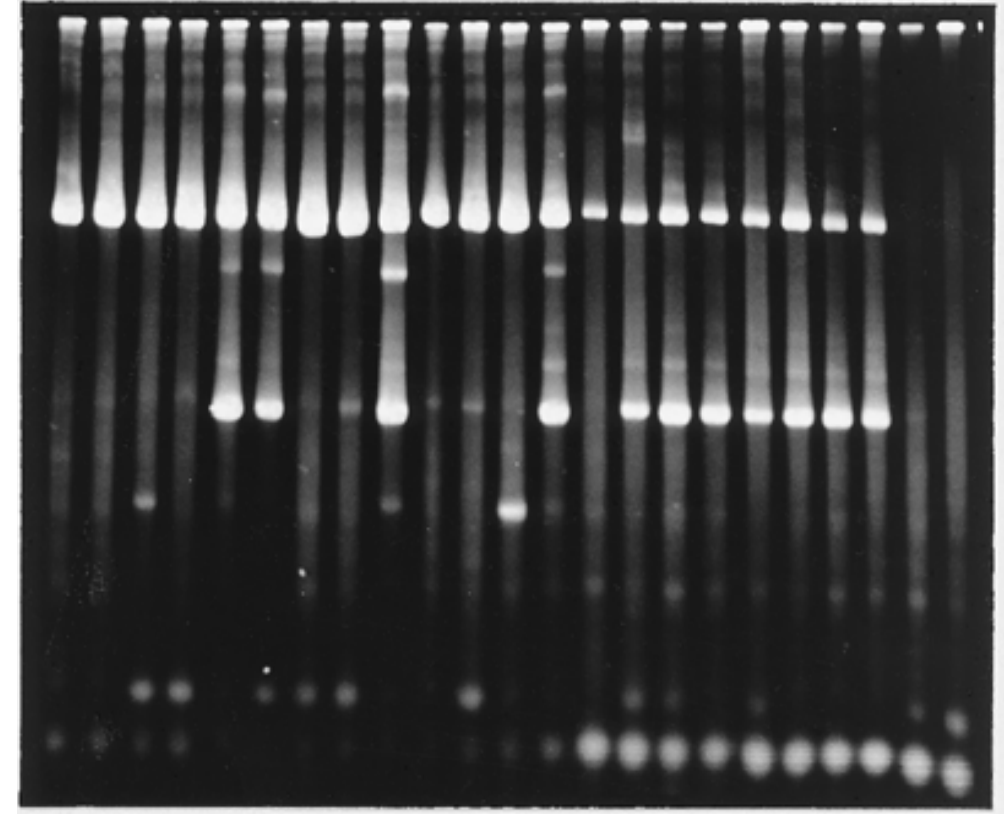

Fig. 3. Polyacrylamide gel electrophoresis of polymerase chain reaction-amplified gene fragments with two sets of primers. The primer set RST31/RST33 produces a 733-bp product from all Xylella fastidiosa strains tested; the primer set $\mathrm{CVC} 1 / \mathrm{CVC} 2$ produces a 270 -bp product from the citrus variegated chlorosis (CVC) strain. Lanes 1 through 13, cultures. Lane 1, Pierce's disease, Florida (ATCC 35881); lane 2, Pierce's disease, Florida (ATCC 35879); lane 3, elm leaf scorch, Washington (ATCC 35873); lane 4, ragweed, Florida (ATCC 358765); lane 5, CVC, Colina, Brazil; lane 6, CVC, Macaubal, Brazil; lane 7, mulberry leaf scorch, Massachusetts (ATCC 35869); lane 8, almond leaf scorch, California (ATCC 358709); lane 9, CVC Catigua, Brazil; lane 10, mulberry leaf scorch, Massachusetts (ATCC 35868); lane 11, Pierce's disease, California (ATCC 35877); lane 12, oak leaf scorch, Washington (ATCC 35874); and lane 13, Vinca rosea inoculated with CVC culture, Sao Paulo, Brazil. Lanes 14 through 23 , extracts of citrus: lanes 14,22 , and 23 , from symptomless trees; and lanes 15 through 21, from trees with CVC symptoms. Lane 14, Florida; lane 15, Bebedouro, Brazil; lanes 16 and 17, Macaubal, Brazil; lane 18, Colina, Brazil; lanes 19 and 20, Catigua, Brazil; lane 21, Monte Aprazivel, Brazil; and lanes 22 and 23, Sao Paulo, Brazil.

tion was observed from a tree that had the CVC strain (data not shown); this tree appeared healthy and probably had a presymptomatic infection of CVC. We have detected, on occasion, $X$. fastidiosa in citrus trees in Florida, using PCR (Figs. 2 and 3, lane 14), but not in association with CB. In a recent survey, 12 trees with $\mathrm{CB}$ were assayed by the mixed primer assay, and no $X$. fastidiosa was detected. Fortunately, we have not detected the strain causing CVC in Florida.

The observation that the CVC strain of $X$. fastidiosa can be distinguished readily from other strains with tRNA consensus primers confirms the previous PCR-based study, which showed that the CVC strain is considerably different from other strains (17). PCR-based assays for $X$. fastidiosa are being used in further studies in Brazil. The search for strains other than CVC continues in citrus and other hosts. Moreover, considerable effort is being made to identify alternate hosts of the CVC strain. However, it should be noted that the incidence of CVC can be dramatically reduced by removal of symptomatic young trees and affected branches of older trees (V. Z. Rodas, personal communication). Thus, infected citrus appears to be a primary source of inoculum for in-grove spread. Whether there are any weed hosts that make a significant contribution to the incidence of CVC has yet to be established.

\section{LITERATURE CITED}

1. Ausubel, F. M., Brent, R., Kingston, R. E., Moore, D. D., Seidman, J. G., Smith, J. A., and Struhl, K. 1987. Current Protocols in Molecular Biology. J. Wiley \& Sons, New York.

2. Beretta, M. J. G., Harakava, R., Chagas, C. M., Derrick, K. S., Barthe, G. A., Ceccardi, T. L., Lee, R. F., Paradela, O., Sugimori, M., and Ribeiro, I. A. 1996. First report of Xylella fastidiosa in coffee. Plant Dis. 80:821.

3. Beretta, M. J. G., Rossetti, V., Teixeira, A. R. R., and Sempionato, O. 1991. Positive diagnostic tests for declinio on plants root-graft inoculated in Brazil. Pages 256-260 in: Proc. 11th Conf. IOCV. R. H. Brlansky, R. F. Lee, and L. W. Timmer, eds. International Organization of Citrus Virologists, Riverside, CA.

4. Chang, C. J., Garnier, M., Zreik, L., Rossetti, I., and Bove, J. M. 1993. Culture and serological detection of Xylella fastidiosa, the xylemlimited bacterium associated with citrus variegated chlorosis disease. Curr. Microbiol. 27: $137-142$.

5. Derrick, K. S., Barthe, G. A., Hewitt, B. G., Lee, R. F., Albrigo, L. G., and Irey, M. S. 1992. Detection of citrus blight by serological assays. Proc. Fla. State Hortic. Soc. 105:26-28.
6. Firrao, G., and Bazzi, C. 1994. Specific iden- tification of Xylella fastidiosa using the polymerase chain reaction. Phytopathol. Mediterr. 33:90-92.

7. Hartung, J. S., Beretta, J., Brlansky, R. H., Spisso, J., and Lee, R. F. 1994. Citrus variegated chlorosis bacterium: Axenic culture, pathogenicity, and serological relationships with other strains of Xylella fastidiosa. Phytopathology 84:591597.

8. Honeycutt, R., and McClelland, M. 1996. Application of the polymerase chain reaction to the detection of plant pathogens. Pages 186 201 in: The Impact of Plant Molecular Genetics. B. W. S. Sobral, ed. Birkhauser, Boston.

9. Hopkins, D. L. 1988. Production of diagnostic symptoms of blight in citrus inoculated with Xylella fastidiosa. Plant Dis. 72:432-435.

10. Hopkins, D. L., Thompson, C. M., Bistline, F. W., and Russo, L. W. 1989. Relationship between xylem-limited bacteria and citrus blight. Proc. Fla. State Hortic. Soc. 102:21-23.

11. Hopkins, D. L., Thompson, C. M., Wichman, R. L., Bistline, F. W., and Russo, L. W. 1995. Effect of inoculation of mature citrus trees in the grove with Xylella fastidiosa on citrus blight incidence. Proc. Fla. State Hortic. Soc. 108:103-106

12. Kitajima, E. W., Bakarcic, M., and FernandezValiela, M. V. 1975. Association of rickettsialike bacteria with plum leaf scald disease. Phytopathology 65:476-479.

13. Lee, R. F., Beretta, M. J. G., Derrick, K. S., and Hooker, M. E. 1992. Development of a serological assay for citrus variegated chlorosis: A new disease of citrus in Brazil. Proc. Fla. State Hortic. Soc. 105:32-35.

14. Lee, R. F., Derrick, K. S., Beretta, M. J. G., Chagas, C. M., and Rosetti, V. 1991. Citrus variegated chlorosis: A new destructive disease of citrus in Brazil. Citrus Ind. 72(10):12-15.

15. Lee, R. F., Marais, L. J., Timmer, L. W., and Graham, J. H. 1984. Syringe injection of water into the trunk: A rapid diagnostic test for citrus blight. Plant Dis. 68:511-513.

16. Minsavage, G. V., Thompson, C. M., Hopkins, D. L., Leite, R. M. V. B. C., and Stall, R. E. 1994. Development of a polymerase chain reaction protocol for detection of Xylella fastidiosa in plant tissue. Phytopathology 84:456461.

17. Pooler, M. R., and Hartung, J. S. 1995. Specific PCR detection and identification of Xylella fastidiosa strains causing citrus variegated chlorosis. Curr. Microbiol. 31:377-381

18. Purcell, H. A., and Hopkins, D. L. 1996. Fastidious xylem-limited bacterial plant pathogens. Annu. Rev. Phytopathol. 34:131-151.

19. Timmer, L. W., Lee, R. F., Brlansky, R. H. Graham, J. H., Albrigo, L. G., Derrick, K. S., and Tucker, D. P. H. 1992. The infectious nature of citrus blight. Proc. Fla. State Hortic. Soc. 105:21-26.

20. Tucker, D. P. H., Lee, R. F., Timmer, L. W. Albrigo, L. G., and Brlansky, R. H. 1984. Experimental transmission of citrus blight. Plant Dis. 68:979-980.

21. Wells, J. M., Raju, B. C., Hung, H-Y., Weisburg, W. G., Mandelco-Paul, L., and Brenner, D. J. 1987. Xylella fastidiosa gen. nov. sp. nov. Gram-negative, xylem-limited, fastidious plant bacteria related to Xanthomonas spp. Int. J. Syst. Bacteriol. 37:136-143.

22. Welsh, J., and McClelland, M. 1991. Genomic fingerprints produced by PCR with consensus tRNA gene primers. Nucleic Acids Res. 19:861866.

23. Wutscher, H. K., Cohen, M., and Young, R. H. 1977. Zinc and water-soluble phenolic levels in the wood for the diagnosis of citrus blight. Plant Dis. Rep. 6:572-576. 